\title{
New Periodicals of 1963-Part II
}

\section{BY LUCIA P. JOHNSON}

INDEXES and abstracting services head the list of new periodicals in 1963. Current events are reflected in several publications on disarmament and international relations. There are the usual number of new scientific publications and these as before have for the most part been listed only in the alphabetical section at the end, distinguished by an asterisk.

Abstracts. Bibliographies. Indexes. The Journal of Economic Abstracts covers twenty-six journals published in sixteen countries in eight languages. The abstracts are in English and in most cases are prepared by the authors of the original articles. This service is published cooperatively by the contributing journals under the auspices of the American Economic Association. A more specialized publication is Atherosclerosis and Hypertension Abstracts prepared with the cooperation of the College of Physicians library in Philadelphia. Although its field is limited, its coverage is comprehensive with pertinent material from over twenty-six hundred foreign and domestic publications. Each issue includes author, corporate source, and subject indexes. $\mathrm{Cu}$ mulative indexes will be published at intervals. The arrangement of Theoretical Chemical Engineering Abstracts is by general subject group. The first issue was not indexed but a projected annual index was mentioned.

The International Social Security Association has replaced the "World Bibliography of Social Security," which was issued as a section of its Bulletin, with a new multilingual publication, Bibliographie Universelle de Sécurité Sociale. This attempts to be a complete bibliography of all nonperiodical literature on this subject. It will also include information on selected periodical articles and notes on current legislation. A semiannual supplement, Recueil Documentaire, will contain bibliographical material
Miss Johnson is a Serials Cataloger in the Descriptive Cataloging Division of the $\mathrm{Li}$ brary of Congress.

on selected aspects of social security. A similar publication in the field of mathematics is the Announcements issued by the Mathematical Sciences Service Bureau (an agency organized to serve three professional organizations: The American Mathematical Society, the Mathematical Association of America, and the Society for Industrial and Applied Mathematics). The first four issues of each year will list mathematical research monographs and informally published lecture notes, while the fifth issue will be a combined membership list for the three organizations.

Several new indexes complete the list of librarians' aids. The International Guide to Indic Studies is the latest in the series of indexes to periodical literature published by the American Bibliographic Service. Each issue lists articles by author with a subject index as well as an index to book reviews of pertinent works. All indexes will be cumulated at the end of each volume. The Index to Jewish Periodicals appears to be a complete author and subject index to some forty-five magazines on Judaism. From Latin America comes Indice Económico Colombiano issued by the Biblioteca de Ciencias Económicas of the Universidad de Antioquia. This publication covers all articles in thirty-three Colombian economic journals.

The Library of International Relations is publishing an annotated index to the books, pamphlets, documents, directories, and periodicals which it receives under the title International Information Service. Each issue will include a geographical index and will supply addresses of magazines listed. This publication supersedes World in Focus which was published from 1945 to 1951 . With the rising tide of scientific confer- 
ences, the Technical Meetings Index should be one of the more valuable serial publications of the year. Each issue will list all known technical meetings to be sponsored by United States or Canadian organizations for the next two years. Information will include name, date and headquarters, sponsor, content, estimated attendance, deadlines for abstracts and papers, and information on publication of papers. Access to this material will be through five indexes by topic, sponsor, date of meeting, location, and deadline.

Areas. Interest in Africa continues to manifest itself in a multiplicity of new publications. From South Africa comes the International Bulletin of the Africa Institute, an organization founded in 1960 as a joint venture of the South African Academy of Science and Arts and the nine major universities in the country. Articles are surprisingly objective in their discussion of the black African countries, their problems, and their relationship to South Africa. RevolutionAfrica, Latin America, Asia is edited in Algeria and published in Lausanne, Switzerland. This is a propaganda magazine from the far Left with a popular format something like the old Coronet. It may be an unstable item for it has already suffered a change of name; the first two issues appeared under the title African Revolution.

In sharp contrast to the magazines above, Greek Heritage will devote itself to classical Greece and its influence on modern Greece and today's world. Published quarterly with hard covers, articles written by experts in a popular style, and many colorful illustrations, this should be one of the more popular magazines if anyone can afford it at $\$ 25.00$ a year.

ART. An important item for art libraries is Master Drawings, a quarterly publication devoted to articles on the sketches and prints of the master painters. Each article is illustrated lavishly with plates, many of which previously have been unpublished. The first issue includes such artists as Goya, Géricault, and Dürer.

Economics. The Journal of Accounting Research is published by the Institute of Professional Accounting of the Graduate School of Business of the University of Chicago and the London School of Economics and Political Science. Papers will deal with all phases of research in accounting, and articles will be published from contributors all over the world. The National Industrial Conference Board's Business Record and its Management Record have been merged to form the Business Management Record. The new publication will include both theoretical and practical articles of interest to the businessman, the labor leader, and the economist, as well as statistics and information on recent mergers and acquisitions. Realm is a large colorful periodical for "women of accomplishment." Articles concern business women, their problems and interests.

The British Journal of Industrial Relations is an academic publication, largely British in interest, but including articles on developments overseas. The first issue features information on British trade union political independence, immigration and unemployment in the United Kingdom, and Soviet wage structure.

Education. The Journal of General Education is published by the University of Bombay and is concerned with theories and methods of liberal arts education at the college level. Teaching Arithmetic; the British Elementary Mathematics Journal is published for the nonspecialist elementary mathematics teacher at the primary level and will emphasize new techniques, philosophies, and apparatus for teaching.

General. This category might better be termed "miscellaneous" since the journals included are general only through the fact that they do not fit neatly into other categories. Folia Humanística is concerned with humanism and all its aspects. Members of the advisory board come from all over the world. The first issue includes articles on the death of Mozart, developments in modern music, and Boris Pasternak. The Rocky Mountain Review is published and edited by faculty members from several colleges in the Rocky Mountain area. There is virtually no limit to the scope of subject matter or geographical location of the authors and the first issue includes articles on China, origin of man in the Americas, and religious toleration. Report; the News of the Month in Perspective is a monthly news magazine which will discuss the important political and cultural events within a framework of Christian perspective. This publication is 
entertainingly written with many photographs in a layout reminiscent of U.S. News and World Report.

InTERNATIONAL AfFaIRs. Reflecting the tensions which have produced the recent world crises and the Nuclear Test Ban Treaty are several new publications on disarmament. War \& Peace is published in London by the Campaign for Nuclear Disarmament and will discuss the world situation as it influences and is influenced by the possibilities of nuclear warfare. From a more academic point of view, Pergamon Press is publishing Disarmament and Arms Control. The editors feel that disarmament is "unprecedented" and that any success will require the formulation of new concepts. The editorial board includes representatives of both political and scientific research centers and it is hoped to provide an international forum for the discussion of this topic.

International Relations is an English language publication from Greece which consists of articles on the reaction of Greece to various international developments and the effect of internal developments on Greek allies, opponents, and neutrals. Most of the papers in the first issue are written by members of the Greek government.

Law. The Modern Practice Commentator will deal with "practice under the federal rules of civil procedure," including both original papers and reprints from the best of other journals. Law Today is the magazine of the Independent Bar Association, a new organization with a conservative bias. The first issue discusses the World Court and proposals to liberalize United States relations with this court-all of which the association opposes. Another publication concerned with international law is the Common Market Law Review published with the cooperation of the British Institute of International and Comparative Law and the Europa Instituut of the University of Leyden. It will include articles by qualified lawyers and others interested in the legal situation of the Common Market, as well as reviews of some of the decisions of the Court of Justice, information on national legislation relevant to the Market, and reviews of literature dealing with the new law.

The Servicio Legislativo de Puerto Rico will publish texts of Puerto Rican laws and resolutions, directories of government officials, and text of United States legislation concerning the Commonwealth with access to all this material through cumulative indexes. At the end of each year the subscriber will receive a bound volume containing all laws and resolutions passed during the year. Similar information on Poland will be issued in Droit Polonais Contemporain, published by the Institute of Legal Sciences of the Polish Academy of Sciences. It will provide information on contemporary Polish laws, regulations, and court decisions with text in English, French, or Russian.

PhILOSOPHY. The Journal of the History of Philosophy is an international journal in English, French, and German sponsored by Claremont College, Stanford University, the University of California, and the Winchester Foundation. A new Dutch publication is Vivarium; a Journal for Mediaeval Philosophy and the Intellectual Life of the Middle Ages, which will study the secular or profane thought in medieval philosophy. Atlantida is a Spanish magazine of current thought primarily on philosophy and religion. Most of the contributors to the first issue appear to be from Spanish and German universities. Systematics is the journal of the Institute for the Comparative Study of History, Philosophy, and the Sciences. This institute in its seventeen years of existence has come to believe in the idea of progress and the usefulness of systematics in reconciling what appear to be irreconcilable differences in theory. Contributions will be welcomed in all branches of history, philosophy, and science that have a bearing on the systematic hypothesis.

Literature. A new "little magazine" is the Stolen Paper Review, published in Arizona. It includes poetry, prose, literary and artistic criticism, and reproduction of art. The contributors appear to have published widely in other literary reviews. A similar publication is The Classic; Johannesburg Quarterly, but this publication has special interest in that it claims to be the only literary magazine published in South Africa by the native population. Le Livre Slovène, published in Ljubljana by the Association des Ecrivains Slovènes, will make available poetry and prose in French by Slovenian writers. It also includes some pieces in 
English translation from the original Slovenian, as well as examples of contemporary art and literary criticism.

Book Week is a new Sunday supplement published by and issued in the New York Herald Tribune. It will also be distributed by the Washington Post and the San Francisco Examiner. Many reviews contain pictures of the authors. The first issue includes reviews by many writers in their own right: Eugene Burdick, André Maurois, Jerome Weidman, and Dorothy B. Hughes.

SCIENCE. Most of the periodicals of note which would appear in this section can be characterized as highly technical or scholarly publications which will be of value only to experts in the field. For this reason they have not been listed here but may be found in the alphabetical listing at the end, distinguished by an asterisk. Those listed below require a little more explanation.

Hommes et Terres du Nord is published by the Institut de Géographie of the University of Lille and the Société de Géographie de Lille, superseding the geographical issue of Revue du Nord and the Bulletin of the Société de Géographie de Lille. Primarily devoted to the northern part of France with some interest in the Netherlands and Belgium, articles will deal with physical, human, and economic geography. Each issue will feature a bibliography of works of current interest. On a less technical plane, Science and Children is published by the National Science Teachers Association, superseding Elementary School Science Bulletin. It hopes to aid teachers in planning their science programs and to this end in addition to the usual articles, each issue will include information on film strips, books, and science equipment available.

SocIal SCIENCES. Trans-action, a publication of the Community Leadership Project of Washington University, is one of the more interesting journals of the year. It attempts to bridge the gap between the social sciences and the general public through a collection of articles on all phases of this immense field, written in a popular way. The first issue includes information on urban renewal, the political situation in the South, the school drop out, the culture of the corner gang, and the public library. All these articles are written by professional social scientists and from their rather specialized point of view.
More technical are two new journals from Germany. Sociologia Internationalis hopes to synthesize the practical and theoretical schools of sociology through the interrelation and comparison of ideas of prominent sociologists from all over the world. The text will be in English, French, German, and Spanish. Deutsche Studien confines itself to Germany and Europe with material on all aspects of German life, especially in comparing East and West Germany. This journal is published by the Ostdeutsch Akademie and the Gesamteuropäische Studienwerk and supersedes Ostbriefs. From the other side of the world, the Center for Japanese Social and Political Studies will publish the Journal of Social and Political Ideas in Japan, hoping to transmit to other countries the social and political ideas and trends as they relate to international and domestic affairs. Each issue will contain translations in English of approximately thirty condensations of Japanese articles.

TechNology. The International Journal of Electrical Engineering Education is edited by the Manchester College of Science and Technology superseding the Bulletin of Electrical Engineering Education. This publication will devote itself to scientific developments which influence methods of education, experiments in new types of courses and curriculums, reports of educational conferences, and book reviews. In a more specialized field, The Textile Institute and Industry will provide a somewhat popular journal reporting new advances in the technology of textile processing written by experts but in language suitable for the nonscientist. This magazine will complement but not replace the institute's Journal.

Recognizing the current interest in the need for control and conservation of the water resources of the world, the Journal of Hydrology will present articles of a technical nature written by experts from all over the world. Another crucial problem today is the agricultural development of Africa and Machinisme Agricole Tropical published by the Centre d'Études et d'Expérimentation du Machinisme Agricole Tropical contains articles on technical improvements, news of technical meetings, and bibliographies of pertinent new publications.

TheATER. Films. Gambit; an International Drama Quarterly contains texts of plays with the hope of making them familiar to 
people who will not have the chance to see them produced. The first issue contains the text of "Vasco" by French playright Georges Shehadé and "Gone" by Dannie Abse. Deploring the low caliber of the current crop of German films and hoping to promote a new climate more conducive to the growth of good film making, Film; Zeitschrift für Film und Fernsehen will be a magazine of articles and criticism with emphasis at present on foreign films. This is a serious magazine in attractive format with little of the sensationalism usually found in magazines in this field.

\section{Periodicals}

Africa Institute. International Bulletin. P.O. Box 630, Pretoria, South Africa. v. 1, no. 1, Feb. 1963. Monthly. Price not given. Atherosclerosis and Hypertension Abstracts. Info, Inc., 55 N. 17th St., Philadelphia. Charter issue, Oct. 1963. Frequency not given. Price not given.

Atlantida; Revista del Pensamiento Actual. Ediciones Rialp, Preciados, 44, Madrid 13. v. 1, Jan./Feb. 1963. Bimonthly. \$7.

Bibliographie Universelle de Sécurité Sociale. World Bibliography of Social Security. General Secretariat of the International Social Security Association, 154, rue de Lausanne, Geneva. v. 1, no. 1, 1963. Quarterly. \$10. for bibliography and its supplement.

Book Week. New York Herald Tribune Inc., 230 West 41st St., New York 36. v. 1 , no. 1 , Sept. 15,1963 . Weekly. Included in Sunday ed., New York Herald Tribune.

British Journal of Industrial Relations. London School of Economics and Political Science, Houghton St., Aldwych, London W.C.2. v. 1, no. 1, Feb. 1963. 3 no. a year. $\$ 6.50$.

Business Management Record. National Industrial Conference Board, Inc., 460 Park Ave., New York 22. May 1963. Monthly. Price not given.

*Carbon. Pergamon Press Inc., 122 East 55th St., New York 22. v. 1, no. 1, Oct. 1963. Frequency not given. $\$ 40$.

The Classic; Johannesburg Quarterly. The Classic Magazine Trust Fund, P.O. Box 6434, Johannesburg. South Africa. v. 1, no. 1, 1963. Quarterly. \$3.

Common Market Law Review. F. B. Rothman \& Co., South Hackensack, N.J. v. 1, no. 1, June 1963. Frequency not given. $\$ 15$.
Deutsche Studien. Carl Schünemann, 28 Bremen, Zweite Schlachtpforte 7, Postfach 34. v. 1 , no. 1, 1963. Quarterly. DM 9,60 for half year.

Disarmament and Arms Control. Pergamon Press, 122 E. 55th St., New York 22. v. 1, no. 1, Summer 1963. Quarterly. $\$ 30$.

Droit Polonais Contemporain. Polish Scientific Publishers, [Warsaw?] v. 1, 1963. Frequency not given. Price not given.

Film; Zeitschrift für Film und Fernsehen. Filmkunst-Verlag, 8 München 2, Promenadeplatz 10. v. 1, no. 1, Apr./May 1963. Monthly. DM 2,80 per issue.

Folia Humanística. Editorial Glarma, S.A., Folgarolas, 15, Barcelona-6, Spain. v. 1, no. 1, Jan. 1963. Monthly. 275 pesetas.

*Folia Primatologica; International Journal of Primatology. Albert J. Phiebig, P.O. Box 352, White Plains, N.Y. v. 1 , no. 1 , 1963. Quarterly. \$15.50.

Gambit; an International Drama Quarterly. Editor, Robert Rietty, Cav., 40 Old Church Lane, London N.W.9. no. 1, 1963. Quarterly. \$4.50.

Greek Heritage. 360 North Michigan Ave., Chicago 60601. v. 1, no. 1, Winter 1963. Quarterly. \$25.

Hommes et Terres du Nord. Société de Géographie de Lille, 116, rue de l'Hôpital Militaire, Lille, France. no. 1, 1963. Semiannual. 10 n.f.

*IRAL; International Review of Applied Linguistics in Language Teaching. Julius Groos Verlag, 69 Heidelberg/Germany, Gaisbergstrasse 6-8. v. 1, no. 1, 1963. Quarterly. \$9.75.

Index to Jewish Periodicals. 16620 Lomond Blvd., Cleveland, Ohio 44120. v. 1, no. 1, June/Aug. 1963. Frequency not given. Price not given. 
Indice Económico Colombiano. Biblioteca de Ciencias Económicas, U.de A., Calle 48 no. 43-7, Medellín, Colombia. v. 1 , no. 1, Oct. 1962. Quarterly. \$6.

International Guide to Indic Studies. American Bibliographic Service, Darien, Conn. v. 1, no. 1, June 1963. Quarterly. Price not given.

International Information Service. Library of International Relations, 660 N. Wabash Ave., Chicago 11. v. 1, no. 1, 1963. Quarterly. \$10.

International Journal of Electrical Engineering Education. Pergamon Press, Ltd., Headington Hill Hall, Oxford, Eng. v. 1, no. 1, June 1963. Quarterly. £3. 10 s.

*International Journal of Engineering Science. Pergamon Press Inc., 122 East 55th St., New York 22. v. 1, no. 1, Jan./Mar. 1963. Quarterly. \$30.

International Relations. 5 Zalocosta St., Athens (134), Greece. no. 1, Nov. 1962. Quarterly. \$8.

*Investigative Urology. Williams \& Wilkins Company, 428 East Preston St., Baltimore 2. v. 1, no. 1, July 1963 . Bimonthly. Price not given.

Journal of Accounting Research. Editor, Graduate School of Business, University of Chicago, Chicago 37. v. 1, no. 1, Spring 1963. Semiannual. $\$ 4.50$.

*The Journal of Asthma Research. 428 E. Preston St., Baltimore 2. v. 1, no. 1, Sept. 1963. Quarterly. \$8.

The Journal of Economic Abstracts. Littauer Center M-12, Harvard University, Cambridge 38, Mass. v. 1, no. 1, Jan. 1963. Quarterly. \$2.

*Journal of Gas Chromatography. 1718 Sherman Ave., Evanston, Ill. v. 1, no. 1, Jan. 1963. Monthly. \$6.

The Journal of General Education. Manager of Publication, University of Bombay, Bombay 1, India. v. 1, no. 1, Jan. 1963. Frequency not given. \$3.

Journal of Hydrology. North-Holland Pub. Co., Postbox 103, Amsterdam, Netherlands. v. 1, no. 1, Mar. 1963. Quarterly. $\$ 15$. per vol.

*Journal of Organometallic Chemistry. Elsevier Publishing Company, P.O. Box 211, Amsterdam-C., Netherlands. v. 1 , no. 1 , Oct. 1963. Frequency not given. \$15. per vol.

Journal of Social and Political Ideas in
Japan. The Chairman, The Center for Japanese Social and Political Studies, Kuwano Building, 2-26 Yoyogi, Shibuya-ku, Tokyo. v. 1 , no. 1 , Apr. 1963.3 no. a year. $\$ 5$.

Journal of the History of Philosophy. Periodicals Department, University of California Press, Berkeley, Calif. 94720. v. 1, no. 1, Oct. 1963. Semiannual. \$5.

Law Today. Independent Bar Association, 550 Fifth Ave., New York 36. v. 1, no. 1, Summer 1963 . Quarterly with 1 or more special issues. $\$ 3$.

Le Livre Slovène. Association des Ecrivains Slovènes, Ljubljana, Tomsiceva 12, Yugoslavia. v. 1, no. 1, May 1963. Frequency not given. 950 dinars.

Machinisme Agricole Tropical. Centre d'Etudes et d'Expérimentation du Machinisme Agricole Tropical, Parc de Tourvoie, Antony, Seine, France. no. 1, Jan./ Mar. 1963. Quarterly. 25 n.f.

Master Drawings. Master Drawings Association, Inc., 33 E. 36th St., New York 16. v. 1, no. 1, Spring 1963. Quarterly. $\$ 10$.

Mathematical Sciences Service Bureau. Announcements. 190 Hope St., Providence 6 , R.I. v. 1 , no. 1 , Dec. 1962.5 no. a year. $\$ 10$.

Modern Practice Commentator. Callaghan \& Co., 165 North Archer Ave., Mundelein, Ill. v. 1, no. 1, May 1963. Quarterly. $\$ 20$.

*Psychotherapy: Theory, Research and Practice. Psychologists Interested in the Advancement of Psychotherapy, Lawrence Bookbinder, Ph.D., 2800 Ewald Circle, Detroit 38. v. 1, no. 1, Aug. 1963. Quarterly. \$8.

Realm. Medalist Publications, Inc., 1801 Prairie Ave., Chicago 16. v. 1, no. 1, Oct. 1963. Monthly. \$7.

*Refractories. Consultants Bureau Enterprises, Inc., 227 West 17th St., New York 11. No. 1/2, Jan./Feb. 1963. Bimonthly. $\$ 16$. (Translation of Russian journal, Ogneupory)

Report; the News of the Month in Perspective. Report Publishing Co., Inc., 166 Madison Ave., New York 16. v. 1, no. 1, Sept. 1963. Monthly. \$4.

Revolution-Africa, Latin America, Asia. 244 East 46th St., New York 17. v. 1, no. 1, May 1963. Monthly. \$6.

(Continued on page 138) 
Slavic competence. This subsection is planning to obtain a speaker in the Slavic field for its program at St. Louis.

Mr. Richards reported on the Teacher Education Section and several Board members noted the changing academic picture, with fewer teachers colleges. Mr. McNeal requested statements from $\mathrm{Mr}$. Richards and Mr. Oboler about the positions of these colleges and the need for the Teacher Education Section.

The University Libraries Section is making studies of academic status, according to Mr. Bentz. The ULS Urban Universities Library Committee is planning a luncheon in St. Louis where a report on the New York metropolitan program of library cooperation will be presented.

Mr. West, chairman of the Advisory Committee on Cooperation with Education-

\section{Periodicals ...}

Rocky Mountain Review. Editor, 1511 Poly Drive, Billings, Mont. v. 1, no. 1, Spring 1963. 2 no. a year. \$2.

*Russian Metallurgy and Mining. Scientific Information Consultants Ltd., 661 Finchley Road, London N.W.2. no. 1, Jan./ Feb. 1963. Bimonthly. \$68. (Translation of Izvestiia. Otdelenie Tekhnicheskikh Nauk. Metallurgiia $i$ Gornoe Delo issued by Akademiia Nauk SSSR).

Science and Children. National Science Teachers Association, 1201 16th St. NW, Washington, D.C. 20036. v. 1, no. 1, Sept. 1963. Monthly (except Jan. and June-Aug.). \$4.

Servicio Legislativo de Puerto Rico. Equity Publishing Corporation, Orford, N.H. v. 1 , no. 1 , May 13,1963 . At least 6 no. during the legislative session. $\$ 30$.

Sociologia Internationalis. Duncker \& Humblot, 1 Berlin 41 (Steglitz), DietrichSchäfer-Weg 9. v. 1, no. 1, 1963. Semiannual. DM 36,-

Solid State Communications. 122 East 55th St., New York 22. v. 1, no. 1, June 1963. Monthly. \$30. (Supplement to Journal of Physics and Chemistry of Solids.)

Stolen Paper Review. 603 Ash, Tempe, Ariz. no. 1, Spring 1963. Semiannual. \$1. Systematics. Coombe Springs Press, King- al and Professional Organizations, noted his concern about its functions. It has held some interesting luncheon meetings with guests from these two areas. He recommended that the Planning and Action Committee consider the purpose of this advisory committee.

Mr. Jackson expressed the hope of the monographs Editorial Board that funds could be provided for an honorarium for authors of monographs. The Editorial Board hopes that additional manuscripts will be submitted.

Mr. Harlow requested that all those responsible for ACRL activities keep the executive secretary informed. Mr. Bailey expressed appreciation to everyone for their cooperation.

The meeting was adjourned at 10:30 P.M.

ston-upon-Thames, England. v. 1, no. 1, June 1963. Quarterly. £2. $2 s$.

Teaching Arithmetic. Pergamon Press, 122 East 55 th St., New York 22. v. 1, no. 1, Spring 1963.3 no. a year. $\$ 2.50$.

Technical Meetings Index. Technical Meetings Information Service, 22 Imperial Drive, New Hartford, N.Y. v. 1, no. 1, Sept. 1963. Quarterly. \$25. (subscription to total service).

The Textile Institute and Industry. The Textile Institute, 10 Blackfriars St., Manchester 3, England. v. 1, no. 1, Jan. 1963. Frequency not given. Price not given.

Theoretical Chemical Engineering Abstracts. Technical Information Company, Ltd., Chancery House, Chancery Lane, London W.C.2. abstracts 1-313, July/Aug. 1963. Frequency not given. Price not given.

Trans-action. Circulation Department, Trans-action, Box 43, Washington University, St. Louis, Mo. 63130. v. 1 , no. 1 , Nov. 1963.6 no. a year. $\$ 3.50$.

Vivarium. Royal VanGorcum Ltd., Assen, Netherlands. v. 1, no. 1, May 1963. Semiannual. \$5.75.

War \& Peace. Campaign for Nuclear Disarmament, 2 Carthusian St., London E.C.1. v. 1, no. 1, Jan./Mar. 1963. Quarterly. $17 s .6 \mathrm{~d}$. 